\title{
Organic and Inorganic Fertilizer Amendments on Sustainable Health of Garden Pea (Pisum sativum L.)
}

\author{
Trudy Tengse A. Sangma ${ }^{1 *}$, Luchon Saikia ${ }^{1}$, Rajen Baruah ${ }^{2}$ and Khatemenla ${ }^{1}$
}

${ }^{1}$ Department of Horticulture, Assam Agricultural University, Jorhat-785013, Assam, India

${ }^{2}$ Department of Soil Science, Assam Agricultural University, Jorhat-785013, Assam, India

*Corresponding author

\begin{tabular}{|l|}
\hline K e y w or d s \\
$\begin{array}{l}\text { Biofertilizer consortium, } \\
\text { Economics, Garden pea, } \\
\text { Quality traits, Yield }\end{array}$ \\
\hline Article Info \\
\hline $\begin{array}{l}\text { Accepted: } \\
\text { 30 March } 2018 \\
\text { Available Online: } \\
10 \text { April } 2018\end{array}$ \\
\hline
\end{tabular}

Garden pea is an important vegetable crop due to its high protein content. Plant nutrients from single source cannot meet with optimum and sustained yield levels. Nutrients have to be supplied from different sources in an integrated manner and balanced amounts. However, information in these aspects in garden pea in Assam is lacking. Keeping in view of the above facts the research was conducted with the objective to study the effect of biofertilizer consortium, FYM, enriched compost and chemical fertilizers on sustainable production and profitability of garden pea. The experiment was laid out in a Randomized Block Design with seven treatments and replicated thrice. The treatments were $\mathrm{T}_{1}$ : NPK @ 20:46:0 kgha ${ }^{-1}+$ FYM @ 5tha ${ }^{-1}(\mathrm{RDF}), \mathrm{T}_{2}: \mathrm{NPK} @ 20: 46: 0 \mathrm{kgha}^{-1}+\mathrm{FYM} @ 5 \mathrm{tha}^{-1}+$ biofertilizer consortium, T : NPK @ 20:46:0 $\mathrm{kgha}^{-1}+\mathrm{FYM} @ 10 \mathrm{tha}^{-1}, \mathrm{~T}_{4}$ : NPK @ 10:46:0kgha ${ }^{-1}+$ FYM @ 10tha ${ }^{-1}+$ biofertilizer consortium, T 5 : Enriched compost @ 3tha ${ }^{-1}$, $\mathrm{T}_{6}$ : Enriched compost @ 1.5 tha ${ }^{-1}+$ biofertilizer consortium and $\mathrm{T}_{7}$ : Biofertilizer consortium. The data recorded were analysed through the Analysis of Variance method. From this study, it can be suggested that a judicial combination of biofertilizers along with FYM, enriched compost and inorganic is beneficial towards improving yield attributes of pea with maximum profit.

\section{Introduction}

The study aims at assessing the effects of biofertilizer consortium and its integration with organic and chemical fertilizers on growth, yield and quality of garden pea on long term basis without any deleterious effect on natural resource base. The common pea (also known as the garden pea or field pea), is a herbaceous annual in the Fabaceae (formerly Leguminoseae) family. It is a legume known universally to fix atmospheric nitrogen with symbiotic activity of Rhizobium leguminosarum. The national yield of pea stands at 9.5 t/ha against the backdrop of Assam's average productivity of $4 \mathrm{t} / \mathrm{ha}$ (Anonymous, 2014).

The importance of FYM in increasing the yield and quality of crops on sustainable basis along with its residual effect on succeeding crops by improving the soil physical conditions and soil fertility is well recognized. Similarly, the use of bio-fertilizers in general and Rhizobium, a symbiotic N-fixing (BNF) bacteria is of vital importance to various 
legumes, as 80 to $90 \%$ of $\mathrm{N}$ requirement of legumes is met through BNF. The use of biological nitrogen fixing systems also warrants the application of FYM as a source of carbon to these microbes and that of nitrogen to the growing plants.

Fertilizers are the key factors in influencing the growth, development and ultimately the yield of crops. Among the various nutrients influencing the crop growth, $\mathrm{N}, \mathrm{P}$ and $\mathrm{K}$ are the most critical under irrigated conditions. Adequate supply of these three major nutrients is essential for crops owing to their wide spread deficiencies in most of the soils and the vital role they play in plant metabolism, growth and development.

\section{Materials and Methods}

The study was conducted using the variety GS-10, under the agro-climatic condition of Jorhat (Assam) during the rabi (OctoberJanuary) season in the Experimental Farm of the Department of Horticulture, Assam Agricultural University, Jorhat, situated at $26^{\circ} 47^{\prime} \mathrm{N}$ latitude and $94^{\circ} 12^{\prime} \mathrm{E}$ longitude at an elevation of $96.6 \mathrm{~m}$ above mean sea level. The prevailing climatic condition of Jorhat is humid subtropical with hot summer, cold winter and high relative humidity and receive a rainfall between $1875 \mathrm{~mm}$ to $2146 \mathrm{~mm}$ (Anonymous, 2014). A total of seven treatments were replicated thrice in a randomized block design. The treatments were $\mathrm{T}_{1}$ : NPK@ 20:46:0 kg ha ${ }^{-1}+$ FYM @ $5 \mathrm{t} \mathrm{ha}^{-1}$ (RDF), T 2 : NPK @ 20:46:0 kg ha ${ }^{-1}+$ FYM @ $5 \mathrm{t} \mathrm{ha}^{-1}(\mathrm{RDF})+$ biofertilizer consortium, $\mathrm{T}_{3}$ : NPK@ @20:46:0 kg ha ${ }^{-1}$ +FYM @ $10 \mathrm{t} \mathrm{ha}^{-1}$, $\mathrm{T}_{4}$ : 1/2 RD N \& RD PK @ 10:46:0 kg ha ${ }^{-1}+$ FYM@10 t ha ${ }^{-1}+$ biofertilizer consortium, $\mathrm{T}_{5}$ : Enriched compost @ $3 \mathrm{t} \mathrm{ha}^{-1}, \mathrm{~T}_{6}$ : Enriched compost@1.5 t ha ${ }^{-1}+$ biofertilizer consortium and $\mathrm{T}_{7}$ : Biofertilizer consortium (Rhizobium + Azotobacter + Azospirillum + PSB). Garden pea (GS-10) was grown in a plot size of
$2.5 \times 1.8 \mathrm{~m}^{2}$ maintaining a spacing of $30 \times 10 \mathrm{~cm}$. Manures were incorporated as basal dose at the time of field preparation. Biofertilizer consortium (Rhizobium + Azotobacter + Azospirillum + PSB) was applied as seed treatment before sowing. In every plot, ten plants away from the margin were tagged for recording the yield and yield attributes. Observational data recorded during field experimentation at different growth stages of the crop and laboratory determination were subjected to the statistical analysis as per the standard procedures to test the significance by calculating ' $F$ ' values as described by Panse and Sukhtame (1985).

The TSS was estimated by a digital refractometer at room temperature and was expressed in ${ }^{0}$ Brix.

Ascorbic acid content was determined using 2, 6-Dichlorophenol indophenol dye method as prescribed by Ranganna (1979).

The oven dried samples of representative pea seeds were analyzed for total nitrogen following Kjeldahl method (Jackson, 1973). Nitrogen content determined as per above procedure was multiplied by 6.25 to get the crude protein content in pea seeds.

Ash content was determined by using dry ashing methods outlined by Ranganna (1986).

The $\beta$-carotene pigment was determined by the method described by Ranganna (1986).

\section{Results and Discussion}

\section{Yield and yield attributes}

The growth and development of pea under different treatments reflected the influence of different integrations upon yield and yield attributes. Growth of garden pea measured in terms of plant height at harvest (Table 1) was 
significantly higher $(56.25 \mathrm{~cm})$ with the application of RD NPK + $5 \mathrm{t} \mathrm{FYM} \mathrm{ha}^{-1}+$ biofertilizer consortium $\left(\mathrm{T}_{2}\right)$ while the lowest plant height $(52.16 \mathrm{~cm})$ was recorded in the treatment receiving biofertilizer consortium alone $\left(\mathrm{T}_{7}\right)$. This might be due to the fact that $\mathrm{N}$-fixer and P-solubilizing microorganism secrete certain organic acids and some biochemical, which are growth promoting in nature. These results are in close conformity with Vimala and Natarajan (2000) who also reported great influence of the integrated nutrient management involving Rhizobium, chemical fertilizers and other bulky organic manure (FYM) on the growth of pea and thereby, its physiological parameters. This superior performance of combined use of FYM and bio-fertilizer may probably be due to augmented nutrient supply to crop by increasing availability through exploitation of natural processes like biological nitrogen fixation, solubilization of insoluble $\mathrm{P}$ and decomposition of organic matter. Therefore, artificial seed inoculation is often needed to restore the population of effective strains of Rhizobium in rhizosphere (Srivastava and Verma, 1984). The treatments did not bring about any significant variation in the number of branch. Similarly, number of days taken for 50 percent flowering was not influenced significantly by fertility management treatments. Furthermore, pod length and pod diameter were found to be insignificant. This might be attributed to the genetic makeup of the variety used. Branching is an undesirable character. 50\% flowering by earliness also indicate the maturity and it is an established fact that pea is a heat unit responsive crop. In the present study, non- significance of maturity by $50 \%$ flowering is quite normal.

The yield attributes (Table 2 and 3) viz., seed per pod (7.58), seed per plant (52.75), shelling percentage $(50.33 \%)$, fresh biomass $(33.58 \mathrm{~g})$ and dry biomass $(10.59 \mathrm{~g})$ were significantly higher under RD NPK + 10t FYM ha ${ }^{-1}\left(\mathrm{~T}_{3}\right)$ while the maximum pod per plant (7.13) was recorded with the application of NPK @ 20:46:0 kg ha ${ }^{-1}$ + FYM @ $5 \mathrm{t} \mathrm{ha}^{-1}(\mathrm{RDF})+$ biofertilizer consortium $\left(T_{2}\right)$. $T_{7}$ (biofertilizer consortium) gave the lowest number of pod per plant (5.80), seed per pod (6.18), seed per plant (35.84), shelling percentage (39.97\%), fresh biomass $(21.77 \mathrm{~g})$ and dry biomass $(7.50$ g). It is clearly evident (Table 4) that the maximum pod yield per plant $(40.88 \mathrm{~g})$ and pod yield per hectare $\left(9.20 \mathrm{t} \mathrm{ha}^{-1}\right)$ was produced in $\mathrm{T}_{3}$ while $\mathrm{T}_{7}$ resulted in the lowest pod yield per plant $(19.95 \mathrm{~g})$ and pod yield per hectare $\left(4.49 \mathrm{t} \mathrm{ha}^{-1}\right)$. The yield is the resultant of various growth, development and yield contributing characters. The effect of any factor on these characters may result in differences in the final green pod yield. Consequent upon variation in the yield contributing characters of garden pea, significant differences in the green pod yield were obvious. Datt et al., (2003) obtained significant increase in green pod yield of pea with increasing level of NPK fertilizers upto $150 \%$ in the presence of farmyard manure. Enhancement in yield and other attributes with FYM may be due to availability of more nutrients to the plants. Moderate increase in plant biomass was observed due to coinoculation with biofertilizer, that consequently increased the availability of nutrients form, as cited by Srivastava and Ahlawat, 1995. Moderate increase in plant biomass could be ascribed to better availability of nutrients as the FYM dose has been doubled to $10 \mathrm{t} \mathrm{ha}^{-1}$ (Jaipaul et al., 2011).

\section{Quality traits}

The highest TSS content of $14.63{ }^{0}$ Brix was obtained in $\mathrm{T}_{2}$ and the lowest $\left(9.83{ }^{\circ} \mathrm{Brix}\right)$ in $\mathrm{T}_{7}$. The reason might be attributed to the role played by the consortium in which different beneficial micro-organisms such as Rhizobium, Azotobacter, Azospirillum and PSB were present. 
Table.1 Effect of different treatments on growth attributing characters of garden pea

\begin{tabular}{|c|c|c|c|}
\hline Treatments & $\begin{array}{l}\text { Plant } \\
\text { height } \\
\text { (cm) }\end{array}$ & $\begin{array}{l}\text { Number of } \\
\text { branch }\end{array}$ & Days to $\mathbf{5 0 \%}$ flowering \\
\hline$T_{1}(\mathrm{NPK} @ 20: 46: 0 \mathrm{~kg}+5 \mathrm{t}$ FYM) & 54.08 & 9.90 & 39.33 \\
\hline $\begin{array}{l}\mathrm{T}_{2} \text { (NPK @ 20:46:0kg + } 5 \text { t FYM + } \\
\text { biofertilizer consortium) }\end{array}$ & 56.25 & 9.77 & 36.67 \\
\hline$T_{3}$ (NPK @ 20:46:0kg + 10 t FYM) & 55.25 & 10.07 & 40.67 \\
\hline $\begin{array}{l}\mathrm{T}_{4}(\mathrm{NPK} @ 10: 46: 0 \mathrm{~kg}+10 \mathrm{t} \text { FYM + } \\
\text { biofertilizer consortium) }\end{array}$ & 54.78 & 9.67 & 39.67 \\
\hline$T_{5}$ (3 t Enriched compost) & 53.93 & 9.83 & 39.00 \\
\hline $\begin{array}{l}\mathrm{T}_{6}(1.5 \text { t Enriched compost }+ \\
\text { biofertilizer consortium) }\end{array}$ & 53.60 & 9.73 & 41.33 \\
\hline $\mathrm{T}_{7}$ (Biofertilizer consortium) & 52.16 & 10.13 & 39.33 \\
\hline S.Ed. & 0.95 & 0.22 & 3.12 \\
\hline $\mathrm{CD}_{0.05}$ & 1.70 & $\mathrm{NS}^{*}$ & $\mathrm{NS}^{*}$ \\
\hline
\end{tabular}

NS*=Non-significant

Table.2 Effect of different treatments on pod formation characters of garden pea

\begin{tabular}{|c|c|c|c|c|c|c|}
\hline Treatments & $\begin{array}{l}\text { Pod } \\
\text { length } \\
(\mathrm{cm})\end{array}$ & $\begin{array}{l}\text { Pod } \\
\text { diameter } \\
(\mathrm{cm})\end{array}$ & $\begin{array}{l}\text { Pod per } \\
\text { plant }\end{array}$ & $\begin{array}{l}\text { Seed per } \\
\text { pod }\end{array}$ & $\begin{array}{l}\text { Seed per } \\
\text { plant }\end{array}$ & $\begin{array}{l}\text { Shelling } \\
\%\end{array}$ \\
\hline $\begin{array}{l}\mathrm{T}_{1} \text { (NPK @ 20:46:0kg + } \\
5 \text { t FYM) }\end{array}$ & 8.87 & 1.81 & 6.42 & 6.34 & 40.70 & 43.42 \\
\hline $\begin{array}{l}\mathrm{T}_{2} \text { (NPK @ 20:46:0kg + } \\
5 \text { t FYM + biofertilizer } \\
\text { consortium) }\end{array}$ & 8.10 & 1.84 & 7.13 & 7.32 & 52.19 & 49.27 \\
\hline $\begin{array}{l}\text { T3 (NPK @ 20:46:0kg + } \\
10 \text { t FYM) }\end{array}$ & 9.73 & 1.85 & 6.96 & 7.58 & 52.75 & 50.33 \\
\hline $\begin{array}{l}\mathrm{T}_{4} \text { (NPK @ 10:46:0kg + } \\
10 \text { t FYM + biofertilizer } \\
\text { consortium) }\end{array}$ & 8.80 & 1.82 & 7.07 & 6.93 & 48.99 & 48.62 \\
\hline 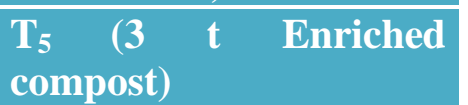 & 7.73 & 1.83 & 6.93 & 6.76 & 46.84 & 47.45 \\
\hline $\begin{array}{l}T_{6}(1.5 \text { t Enriched } \\
\text { compost }+ \text { biofertilizer } \\
\text { consortium) }\end{array}$ & 8.70 & 1.88 & 6.87 & 6.58 & 45.20 & 46.50 \\
\hline $\begin{array}{l}\mathrm{T}_{7} \quad \text { (Biofertilizer } \\
\text { consortium) }\end{array}$ & 8.17 & 1.80 & 5.80 & 6.18 & 35.84 & 39.97 \\
\hline S.Ed. & 0.62 & 0.04 & 0.22 & 0.14 & 2.01 & 0.66 \\
\hline $\mathrm{CD}_{0.05}$ & NS* & NS* & 0.67 & 0.43 & 6.05 & 2.00 \\
\hline
\end{tabular}


Table.3 Effect of different treatments on fresh and dry biomass of garden pea

\begin{tabular}{|c|c|c|}
\hline Treatments & $\begin{array}{l}\text { Total fresh biomass } \\
\text { (g) }\end{array}$ & $\begin{array}{l}\text { Total dry biomass } \\
(\mathrm{g})\end{array}$ \\
\hline $\mathrm{T}_{1}(\mathrm{NPK} @ 20: 46: 0 \mathrm{~kg}+5 \mathrm{t}$ FYM) & 27.26 & 9.07 \\
\hline $\begin{array}{l}\mathrm{T}_{2} \text { (NPK @ 20:46:0kg+ } 5 \text { t FYM + } \\
\text { biofertilizer consortium) }\end{array}$ & 30.75 & 10.06 \\
\hline T3 (NPK@ 20:46:0kg + 10 t FYM) & 33.58 & 10.59 \\
\hline $\begin{array}{l}\mathrm{T}_{4} \text { (NPK@10:46:0kg + } 10 \text { t FYM + } \\
\text { biofertilizer consortium) }\end{array}$ & 25.21 & 8.21 \\
\hline$T_{5}(3 \mathrm{t}$ Enriched compost) & 28.59 & 9.05 \\
\hline $\begin{array}{lll}\mathrm{T}_{6} & \left(\begin{array}{ccc}1.5 & \mathrm{t} & \text { Enriched }\end{array} \text { compost }\right. \\
\text { biofertilizer consortium }) & \end{array}$ & 24.37 & 8.69 \\
\hline $\mathrm{T}_{7}$ (Biofertilizer consortium) & 21.77 & 7.50 \\
\hline S.Ed. & 1.48 & 0.53 \\
\hline $\mathrm{CD}_{0.05}$ & 4.45 & 1.61 \\
\hline
\end{tabular}

Table.4 Effect of different treatments on yield of garden pea

\begin{tabular}{|c|c|c|c|}
\hline Treatment & $\begin{array}{l}\text { Yield } \\
\text { per plant } \\
\text { (g) }\end{array}$ & $\begin{array}{l}\text { Yield } \\
\left(\mathbf{t ~ h a}^{-1}\right)\end{array}$ & $\begin{array}{l}\text { Percentage increase or } \\
\text { decrease over RD of } \\
\text { fertilizer }\left(\mathrm{T}_{1}\right) \\
\%\end{array}$ \\
\hline T1 (NPK@ 20:46:0kg + 5 t FYM) & 35.77 & 8.05 & - \\
\hline $\begin{array}{l}\mathrm{T}_{2}(\mathrm{NPK} @ 20: 46: 0 \mathrm{~kg}+5 \text { t FYM + } \\
\text { biofertilizer consortium) }\end{array}$ & 39.57 & 8.90 & 10.55 \\
\hline T3 (NPK@ 20:46:0kg + 10 t FYM) & 40.88 & 9.20 & 14.38 \\
\hline $\begin{array}{l}\text { T4 (NPK@10:46:0kg + } 10 \text { t FYM } \\
\text { + biofertilizer consortium) }\end{array}$ & 38.64 & 8.69 & 7.90 \\
\hline $\mathrm{T}_{5}(3 \mathrm{t}$ Enriched compost) & 37.37 & 8.41 & 4.47 \\
\hline $\begin{array}{l}\mathrm{T}_{6}(1.5 \mathrm{t} \text { Enriched compost }+ \\
\text { biofertilizer consortium) }\end{array}$ & 36.05 & 8.11 & 0.74 \\
\hline $\mathrm{T}_{7}$ (Biofertilizer consortium) & 19.95 & 4.49 & (-) 44.22 \\
\hline S.Ed. & 1.52 & 0.34 & - \\
\hline $\mathrm{CD}_{0.05}$ & 4.55 & 0.61 & - \\
\hline
\end{tabular}


Table.5 Effect of different treatments on quality of garden pea

\begin{tabular}{|c|c|c|c|c|c|}
\hline Treatment & $\begin{array}{l}\text { TSS } \\
\left({ }^{0} \text { Brix }\right)\end{array}$ & $\begin{array}{l}\text { Crude } \\
\text { protein }(\%)\end{array}$ & $\begin{array}{l}\text { Ash content } \\
(\%)\end{array}$ & $\begin{array}{l}\text { Ascorbic } \\
\text { acid } \\
\left(\mathrm{mg} 100 g^{-1}\right)\end{array}$ & $\begin{array}{l}\boldsymbol{\beta} \text {-Carotene } \\
\left(\mu g g^{-1}\right)\end{array}$ \\
\hline $\begin{array}{l}\mathrm{T}_{1}(\mathrm{NPK} @ 20: 46: 0 \mathrm{~kg}+5 \mathrm{t} \\
\text { FYM) }\end{array}$ & 13.03 & 21.03 & 3.48 & 8.43 & 261.09 \\
\hline $\begin{array}{l}\mathrm{T}_{2} \text { (NPK @ 20:46:0kg + } 5 \mathrm{t} \\
\text { FYM }+ \text { biofertilizer } \\
\text { consortium) }\end{array}$ & 14.63 & 22.06 & 3.70 & 9.52 & 274.24 \\
\hline $\begin{array}{l}\text { T3 }(\mathrm{NPK} @ 20: 46: 0 \mathrm{~kg}+10 \\
\text { t FYM) }\end{array}$ & 13.67 & 20.53 & 3.50 & 8.36 & 241.15 \\
\hline $\begin{array}{l}\mathrm{T}_{4} \text { (NPK @ 10:46:0kg + } 10 \\
\mathrm{t} \text { FYM + biofertilizer } \\
\text { consortium) }\end{array}$ & 14.10 & 21.59 & 3.68 & 8.53 & 267.12 \\
\hline $\mathrm{T}_{5}(3 \mathrm{t}$ Enriched compost $)$ & 11.77 & 20.37 & 3.55 & 8.27 & 218.21 \\
\hline $\begin{array}{l}\mathrm{T}_{6}(1.5 \mathrm{t} \text { Enriched compost } \\
\text { + biofertilizer consortium) }\end{array}$ & 10.63 & 21.32 & 3.57 & 8.38 & 252.18 \\
\hline $\begin{array}{ll}\mathrm{T}_{7} & \text { (Biofertilizer } \\
\text { consortium) }\end{array}$ & 9.83 & 20.16 & 3.46 & 7.93 & 213.27 \\
\hline S.Ed. & 0.05 & 0.54 & 0.02 & 0.21 & 0.10 \\
\hline $\mathrm{CD}_{0.05}$ & 0.09 & 0.97 & 0.04 & 0.38 & 0.19 \\
\hline
\end{tabular}

Fig.1 Economics of garden pea cultivation

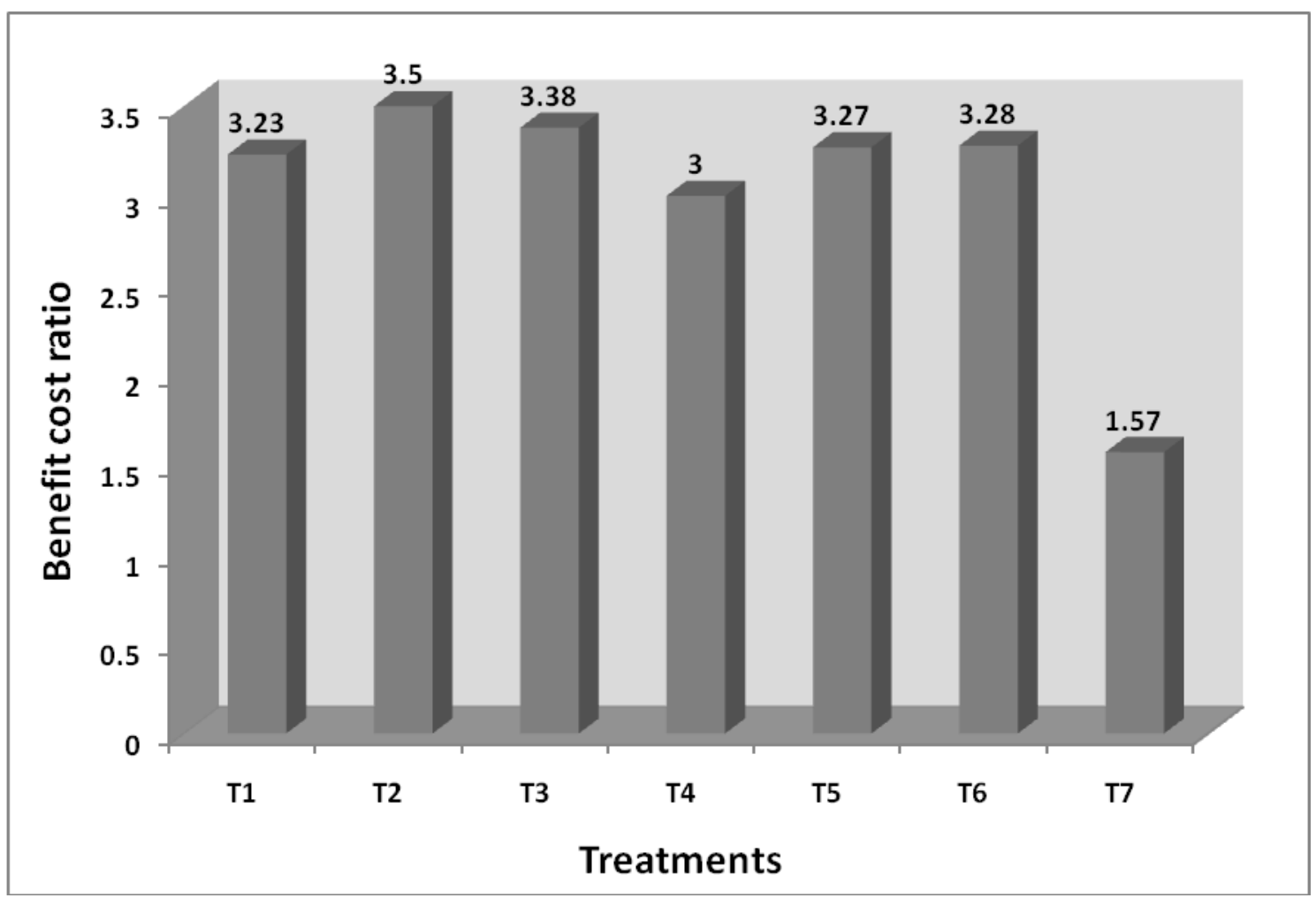


Koshalendra et al., (1992) have earlier revealed that total polysaccharides and sugars in crops increased due to application of organic manures, which resulted due to the higher availability of phosphorus which is a constituent of ADP, ATP and other high energy compounds. This increase in TSS with the application of organics may be attributed to increase in sugar phosphates polysaccharides as phosphorus is one of the important constituent. Sharma and Rana (1993) also reported increase in TSS in pea with the application of NPK. Similarly, in present study, the $T_{1}$ was also found with second highest amount of TSS content.

Crude protein was significantly highest $(22.06 \%)$ in $\mathrm{T}_{2}$ while $\mathrm{T}_{7}$ gave the lowest $(20.16 \%)$. This result might be due to physiological influence of Rhizobium and phosphobacteria present in consortium, on the activity of number of enzyme along with the inorganic nutrients such as nitrogen, which is the chief constituent of protein, could have altered the contents to the desired levels.

The results obtained are in line with the findings of Vimala and Natarajan (2000) in pea. The increase in protein due to increased supply of P by PSB and due to nodulation has led to increased $\mathrm{N}$ fixation which in turn had positive effect on photosynthetic ability and rate. Similar findings of Jain et al., (1999) in chick pea and Naagar and Meena (2004) in cluster bean could also be put forward for supporting the present results.

Pod of pea, the highest sink serves as the best source of minerals such as nitrogen, phosphorus, potash, calcium etc. Since pea is being a legume crop its pod yield definitely lend support to harvesting of more nitrogen in terms of protein by consuming energy provided by phosphorus. Ash represents in totality the amount of the different minerals.
Maximization of ash content represents a positive quantum of minerals present in the pods. In the present investigation, the maximum yield $(3.70 \%)$ was obtained in $\mathrm{T}_{2}$ and $\mathrm{T}_{7}$ accounted for the lowest yield $(3.46 \%)$. Product with higher ash content is expected to have relatively higher mineral content. In accordance, Pavan et al., (2006) recorded the highest protein content by applying 1:1 inorganic and organic.

Ascorbic acid content of $\mathrm{T}_{2}$ was recorded as the highest $\left(9.52 \mathrm{mg} 100 \mathrm{~g}^{-1} \mathrm{FW}\right.$ ) while the lowest ascorbic acid content was obtained in $\mathrm{T}_{7}$ with only $7.93 \mathrm{mg} \quad 100 \mathrm{~g}^{-1} \quad \mathrm{FW}$. Improvement in ascorbic acid content in pea seeds with RD NPK + 5 t FYM ha ${ }^{-1}+$ biofertilizer consortium ( $\left.\mathrm{T}_{2}\right)$ application may be because of slow but continuous supply of all major and micro-nutrients, might have helped in the assimilation of carbohydrates and in turn synthesis of ascorbic acid. Bahadur et al., (2009) and Jaipaul et al., (2011) also noticed significantly higher ascorbic acid content in lettuce where organic manures were combined with Azotobacter or VAM.

In consonance to $\mathrm{T}_{2}$ as superior in other quality parameters (Table 5) viz., TSS, ascorbic acid, crude protein, ash content, the $\beta$-carotene content $\left(274.24 \mu \mathrm{g} \mathrm{g}^{-1} \mathrm{FW}\right)$ was also found to be superior, while $\mathrm{T}_{7}$ gave the lowest $\beta$-carotene content $\left(213.27 \mu \mathrm{g} \mathrm{g}^{-1} \mathrm{FW}\right)$.

Increased availability and uptake of nutrients particularly micro-nutrients may be one of the reasons for improved carotenoids content in pea (Worthington, 2001). The soil amended with compost or FYM increased the boron absorption of soil, particularly at low soil $\mathrm{pH}$ (Yermiyahu and Keren, 1995). Therefore, the increased availability of B may have contributed for increased carotenoids content. Furthermore, compost or farmyard manures 
are known to contain vitamins (vitamin $\mathrm{B}_{12}$ and other vitamins) with higher hormonal and enzymatic activity which has been reported to affect the vitamin synthesis (Maronik and Vasilchenko, 1964).

\section{Economic analysis}

The economic analysis (Fig. 1) of the different treatments produced a unique reflection on the part of cost economics. It was found that $T_{2}$ produced the maximum benefit cost ratio of $3.50 . \mathrm{T}_{7}$ showed the least benefit cost ratio of only 1.57 against per Re.1.00 invested. Even though the highest percentage increase $(14.38 \%)$ in pod yield over the control was obtained in $\mathrm{T}_{3}$, the pod yield was increased 10.55 per cent over control along with highest benefit cost ratio (3.50) in the treatment receiving RD NPK + 5t FYM ha ${ }^{-1}+$ biofertilizer consortium $\left(\mathrm{T}_{2}\right)$. This was in agreement with the result of Bairwa et al., (2009). Gopinath et al., (2008) reported that in bell pepper the highest gross margin and $\mathrm{B}$ : $\mathrm{C}$ ratio were recorded under integrated nutrient management treatment in comparison to treatments containing only organic sources of nutrients.

This study shows that integrated use of recommended dose of fertilizers (NPK) along with $5 \mathrm{t} \mathrm{ha}^{-1}$ of FYM and microbial consortium not only resulted in an adequate productivity of garden pea but could also be a worthwhile management skill for attaining economic yield. The investigation opens up avenues for furtherance of research in both agronomical and biochemical field.

\section{Acknowledgements}

We are grateful to the Head, Department of Horticulture, for her constant support and the Director, Post Graduate Studies, for providing all the necessary facilities throughout the research. Finally, we would also like to thank the anonymous referees for the constructive comments on the manuscript.

\section{References}

Anonymous, 2014. National Horticulture Board, Ministry of Agriculture, Government of India 85, Institutional Area, Sector-18, Gurgaon-122 015, India.

Bahadur, A., Singh, J., Singh, K.P., Upadhyay, A.K. and Rai, M. 2009. Morpho-physiological, yield and quality traits in lettuce (Lactuca sativa) as influenced by use of organic manures and biofertilizers. Indian Journal of Agricultural Sciences, 79, 282-285.

Bairwa, H.L., Mahawer, L.N., Shukla, A.K., Kaushik, R.A. and Sudhar Mathur, A.D. 2009. Response of integrated nutrient management on growth, yield and quality of okra (Abelmoschus esculentus). Indian Journal of Agricultural Sciences, 79(5), 381-384.

Datt, N., Sharma, R.P. and Sharma, G.D. 2003. Effect of supplementary use of farmyard manure along with chemical fertilizers on productivity and nutrient uptake by vegetable pea (Pisum sativum) and build-up of soil fertility in Lahaul valley of Himachal Pradesh. Indian Journal of Agricultural Sciences. 73, 266-268.

Gopinath, K.A., Saha, S., Mina, B.L., Kundu, S., Selvakumar, G. and Gupta, H.S. 2008. Effect of organic manures and integrated nutrient management on yield potential of bell pepper (Capsicum annuum) varieties and on soil properties. Archives of Agronomy and Soil Science, 54, 127-137.

Jackson, M.L. 1973. Soil Chemical analysis. Prentice Hall of India. Pvt. Ltd. New Delhi.

Jain, P.C., Kushwaha, P.S. and Dhakad, U.S. (1999). Response of chick pea (Cicer arietinum L.) to phosphorus and 
biofertilizers. Legume Research, 22(4), 241-244.

Jaipaul, Sharma, S., Dixit, A.K. and Sharma, A.K. 2011. Growth and yield of capsicum and garden pea as influenced by organic manures and biofertilizers. Indian Journal of Agricultural Sciences, 81(7), 637-642.

Koshalendra, T., Solankey, B.S. and Shinde, D.A. 1992. Effect of phosphorus levels and genotypes on quality of soybean seeds. Legume Research, 15(2), 76-80.

Maronik, A.V. and Vasilchenko, V.F. 1964. Biologically active substances in organic fertilizers and their significance in plant nutrition. Journal of Agrobiology, 1, 16-28.

Naagar, K.C. and Meena, N.L. 2004. Effect of phosphorus, sulphur and phosphate solubulizing bacteria on yield components, yield and quality of cluster bean [Cyamopsis tetragonoloba (L.) Taub]. Legume Research, 27(1), 27-31.

Panse, V.G. and Sukhtame, P.U. 1985. Statistical Methods for Agricultural Workers. Indian Council Agricultural Research, New Delhi, 145-152.

Pavan, Y., Singh, P. and Yadav, R.L. 2006. Effect of organic manures and nitrogen levels on growth, yield and quality of okra. Indian Journal of Horticulture, 63(2), 215-217.

Ranganna, S. 1979. Handbook of Analysis and Quality for Fruit and Vegetable Products. Tata McGraw-Hill Publishing Company Ltd., New Delhi. 1112.
Ranganna, S. 1986. In: Handbook of Analysis and Quality for Fruit and Vegetable Products. Tata McGraw-Hill Publishing Company Ltd., New Delhi. 1112.

Sharma, R.P. and Rana, D.S. 1993. Nutrient management in vegetable crops for sustainable production. Fertilizer News. 38(7), 31-34.

Srivastava, S.N.L. and Verma, S.C. 1984. Effect of nitrogen, Rhizobium and techniques of phosphorus application on yield and quality of field pea (Pisum sativum L. var Arvense poir.). Legume Research, 7(1), 37-42.

Srivastava, T.K. and Ahlawat, I.P.S. 1995. Response of pea (Pisum sativum L.) to phosphorus, molybdenum and biofertilizers. Indian Journal of Agronomy, 40, 630-635.

Vimala, B. and Natarajan, S. 2000. Effect of nitrogen, phosphorus and biofertilizers on pod characters, yield and quality in pea (Pisum sativum L. spp. hortense). South Indian Horticulture, 48(1-6), 6063.

Worthington, V. 2001. Nutritional quality of organic versus conventional fruits, vegetables and grains. Journal of Alternative and Complimentary Medicine, 7, 161-173.

Yermiyahu, U. and Keren, R. 1995. Boron sorption by soil in the presence of composted organic matter. Soil Science Society of America, 59, 405-409.

\section{How to cite this article:}

Trudy Tengse A. Sangma, Luchon Saikia, Rajen Baruah and Khatemenla. 2018. Organic and Inorganic Fertilizer Amendments on Sustainable Health of Garden Pea (Pisum sativum L.). Int.J.Curr.Microbiol.App.Sci. 7(04): 3664-3672. doi: https://doi.org/10.20546/ijcmas.2018.704.412 